\title{
Keterampilan Menulis dengan Model Pakem melalui Teknik 'Menjadi Wartawan Junior' di Sekolah Dasar
}

\author{
Isah Cahyani, \& Daris Hadianto D \\ Departemen Pendidikan Bahasa dan Sastra Indonesia, Universitas Pendidikan Indonesia \\ isahcahyani@upi.edu; darishadianto@upi.edu
}

How to cite (in APA Style): Cahyani, I., \& Hadianto, D. (2019). Keterampilan menulis dengan model pakem melalui teknik 'menjadi wartawan junior' di sekolah dasar. Jurnal Pendidikan Bahasa dan Sastra, 19(2), 139-149. DOI: https://doi.org/10.17509/bs_jpbsp.v19i2.24781

Article History: Received (31 July 2019); Revised (16 September 2019); Accepted (1 October 2019). Journal homepage: http://ejournal.upi.edu./index.php/BS_JPBSP

\begin{abstract}
Abstrak: Penelitian ini dilatarbelakangi dengan kondisi kemampuan menulis siswa yang masih rendah. Salah satu metode yang dipandang tepat adalah model PAKEM dengan memposisikan siswa menjadi wartawan junior. Metode penelitian yang digunakan adalah eksperimen kuasi dengan pendekatan kuantitatif. Pendekatan kuantitatif digunakan untuk memperoleh gambaran tetang kemampuan siswa dalam menulis laporan hasil wawancara melalui teknik 'Menjadi Wartawan Junior'. Selain itu, penelitian ini juga menggunakan pendekatan kualitatif untuk mendeskripsikan data profil kemampuan siswa dalam menulis laporan hasil wawancara melalui teknik 'Menjadi Wartawan Junior' sebelum pendekatan pembelajaran menulis melalui teknik 'Menjadi Wartawan Junior' diterapkan. Teknik 'Menjadi Wartawan Junior' efektif untuk meningkatkan kemampuan siswa menulis laporan berdasarkan pada kemampuan kelas eksperimen dengan kenaikan rata-rata skor pretes 57,47 menjadi 78,50 pada rata-rata skor Postest. Sementara, rata-rata akhir nilai kelas kontrol sebesar 57,00 pada pretes dan meningkat 68,78 pada rata-rata skor Postest. Terdapat perbedaan gain sebesar 21,03 pada kelompok eksperimen dan11,78 pada kelompok kontrol. Hal ini membuktikan kemampuan menulis dapat ditingkatkan dengan model PAKEM melalui teknik wartawan junior.
\end{abstract}

Kata kunci: keterampilan menulis; model PAKEM; teknik menjadi wartawan junior

\section{Writing Skills with Model PAKEM through the 'Becoming a Junior Journalist' Technique in Elementary School}

\begin{abstract}
This research is motivated by the condition of students' writing abilities that are still low. One method that is considered appropriate is the PAKEM model by positioning students as junior journalists. The research method that I use is a quasi-experimental research method with a quantitative approach. The quantitative approach is used to obtain a picture of the ability of students to write reports on interviews through the technique of 'Becoming a Junior Reporter'. In addition, this study also uses a qualitative approach to describe the profile data of students' ability to write reports on the results of interviews through the technique of 'Becoming a Junior Journalist' before the learning approach to writing through the 'Becoming a Junior Journalist' technique is applied. The 'Become a Junior Journalist' technique is effective for improving students' ability to write reports based on an increase in the average pretest score of 57.47 to 78.50 on the average posttest score. Meanwhile, the final average value of the control class was 57.00 in the pretest and increased by 68.78 on the average posttest score. There was a difference in gain of 21.03 in the experimental group and 11.78 in the control group. This proves that writing ability can be improved with the PAKEM model through junior journalist techniques. Keywords: writing skills; the PAKEM model; the technique of being a junior journalist
\end{abstract}




\section{PENDAHULUAN}

Keterampilan menulis sangat penting karena diperlukan oleh setiap orang agar dapat hidup dan bertahan hidup dalam masyarakat modern. Keterampilan menulis merupakan wujud kemampuan berpikir tingkat tinggi. Dalam masyarakat modern, orang yang dapat menggenggam atau menaklukkan dunia adalah orang yang memiliki kemampuan berpikir tingkat tinggi. Orang yang memiliki kemampuan berpikir tingkat tinggi memiliki ketajaman berpikir yang pemikirannya dapat menggerakkan pikiran orang lain. Sebaliknya, orang yang kemampuan berpikirnya hanya pada level rendah atau dasar, biasanya ia hanya mampu mengerjakan pekerjaan yang mengandalkan kemampuan fisik (Centeno Vazquez, 2013; KoUn, 2014).

Untuk itu, keterampilan menulis menjadi salah satu keterampilan berbahasa yang harus dikuasai oleh para peserta didik dan diajarkan di sekolah. Namun, kenyataan menunjukkan bahwa keterampilan menulis dianggap sebagai keterampilan berbahasa yang sangat kompleks sehingga hasilnya kurang menggembirakan. Para peserta didik menemui banyak kendala dalam menguasai keterampilan menulis. Hasil penelitian internasional menyatakan bahwa lebih dari $50 \%$ siswa Indonesia berkemampuan rendah dalam menulis. Hal ini ditemukan dalam penelitian Puspendik (2011). Berbagai penelitian dilakukan untuk menemukan berbagai penyebab rendahnya kemampuan menulis siswa Indonesia. Berdasarkan analisis tingkat kesulitan menulis, paling banyak dialami oleh peserta didik SD adalah menulis ekspresif. Ada tiga alasan yang menyebabkan kesulitan menulis ekspresif. Pertama, teknik penugasan dalam pembelajaran menulis yang dilakukan guru kurang sesuai, karena pembelajaran menulis merupakan proses menuangkan gagasan secara terbimbing sehingga mampu memotivasi peserta didik untuk menulis dengan baik. Kedua, waktu yang diberikan kurang cukup sehingga peserta didik mengalami kesulitan untuk merefleksi berbagai gagasan yang akan dituangkan. Ketiga, peserta didik yang kurang memiliki keterampilan metakognitif merasakan lebih sulit menulis jika dibandingkan dengan peserta didik yang normal (Lerner, 2007b; Tarigan, 2008) .

Dalam hal ini, guru hendaknya sensitif terhadap akibat sikap negatif peserta didik berkesulitan menulis. Guru hendaknya memberikan motivasi kepada peserta didik untuk menulis. Tingkat dan jenis kesulitan menulis yang dirasakan dan dialami peserta didik pun beragam. Ada peserta didik yang mengalami kesulitan menulis hanya dalam memulai atau mengawali menulis, sulit ketika mengekspresikan gagasan, perasaan, dan kehendaknya, sulit memilih kata-kata (diksi yang tepat), sulit mengembangkan gagasan, sulit menerapkan ejaan, menulis kata di, ke yang berfungsi sebagai preposisi dan berfungsi sebagai awalan, sulit menulis kata berimbuhan gabungan dua kata kombinasi, sulit merangkaikan kata menjadi kalimat, sulit menentukan tema, sulit memilih topik, sulit membuat judul, dan sulit mengakhir karangan. Guru membantu pelajar agar mereka menyadari menulis merupakan kegiatan yang menuntut keaktifan, proses eksplorasi, dan pengorganisasian pikiran. Bahkan guru hendaknya menggunakan aktivitas yang berorientasi pada upaya membangkitkan rasa ingin tahu, semangat, dan prediksi (Leontis, 2019; Lerner, 2017; Nimehchisalem, 2014; Rohrman, 2006)

Menulis sebagai sebuah kegiatan yang produktif merupakan kegiatan yang berproses secara sadar dan bertujuan mengekspresikan sesuatu secara kreatif, mengolah, mengubah, menambah, mengurangi, memilah, memilih, mengidentifikasi, menganalisis, menyiasati, mengklasifikasi, menerangkan, dan menggeneralisasi isi atau materi komunikasi. Dengan demikian, menulis sebagai sebuah kegiatan produktif, kreatif, dan ekspresif selalu menghasilkan sesuatu secara konkret, ada wujudnya dan ada jelmaan bentuknya yang secara visual dapat dibaca (EslavaSchmalbach \& Gómez-Duarte, 2013; Lerner, 2007a; Nimehchisalem, 2014). Untuk semua kegiatan tersebut, tidak semua orang dapat melalukannya secara alamiah karena kemahiran menulis harus melalui latihan. Model pembelajaran keterampilan menulis 
bahasa Indonesia diupayakan mampu mengembangkan potensi peserta didik sehingga pembelajaran menjadi aktif, kreatif, efektif, dan menyenangkan. Model pembelajaran aktif, kreatif, efektif, dan menyenangkan diharapkan mengubah pembelajaran menulis bahasa Indonesia menjadi lebih bermakna.

Untuk hal tersebut, proses pendidikan melalui proses pembelajaran dapat memanfaatkan model pembelajaran aktif, kreatif, efektif, dan menyenangkan. Salah satu di antaranya, pembelajaran menulis bahasa Indonesia dapat memanfaatkan teknik "Menjadi Wartawan Junior' sehingga pembelajaran tidak hanya sebatas kelas melainkan ada perluasan keluar ruangan kelas sebagai laboratorium belajar. Hal ini terutama untuk keperluan mengajar yang efektif. Berdasarkan hasil analisis lapangan diketahui bahwa akar penyebab masalah di atas bermuara pada strategi pembelajaran yang masih berorientasi produk dan penugasan. Strategi pembelajaran kurang mampu membangkitkan keterampilan menulis, kurang mengembangkan kemampuan percaya diri, kurang mampu membangun komunikasi pembelajaran efektif, kolaborasi, refleksi, dan evaluasi. Bahkan pembelajaran kurang memanfaatkan model-model pembelajaran mutakhir. Dengan demikian, agar peserta didik mampu menulis dengan ekspresif, pembelajaran menulis dapat dilakukan dengan model-model pembelajaran aktif, aktif, kreatif, efektif, dan menyenangkan, sehingga pembelajaran menulis lebih bermakna.

mengamukakan bahwa menulis adalah menuangkan ide ke dalam suatu bentuk visual. Menulis adalah mengungkapkan bahasa dalam bentuk simbol gambar. Menulis adalah suatu aktivitas kompleks yang mencakup gerakan lengan, tangan, jari, dan mata secara terintegrasi. Menulis juga terkait dengan pemahaman bahasa dan berbicara Abdurrahman (2009,p.224). Selain itu, menulis sangat penting bagi pendidikan karena memudahkan para pelajar berpikir. Juga dapat menolong kita berpikir secara kritis. Juga dapat memudahkan kita merasakan dan menikmati hubunganhubungan, memperdalam daya tanggap atau persepsi kita, memecahkan masalah-masalah yang kita hadapi, menyusun urutan bagi pengalaman Tarigan (2008,p.22). Menulis pada dasarnya bukan hanya sekedar menuangkan bahasa ujaran ke dalam sebuah tulisan, tapi merupakan mekanisme curahan ide, gagasan atau ilmu yang dituliskan dengan struktur yang benar, berkoheresi dengan baik antar paragraf dan bebas dari kesalahankesalahan mekanik seperti ejaan dan tanda baca (Epstein-Jannai, 2007; Sazzad, 2019). Penyempurna definisi di atas, menulis adalah akumulasi dari beberapa paragraf yang tersusun dengan sistematis, koheren, unity, ada bagian utama pengantar, isi, dan penutup, ada progresi, semuanya memperbincangkan sesuatu serta tertulis dalam bahasa yang sempurna (Favis, 2009; Kress, 1980).

Salah satu cara yang dapat ditempuh adalah mengelola pembelajaran yang dapat memberikan kesempatan kepada anak untuk terlibat dan mengekspresikan segala potensi yang dimilikinya. Salah satu strategi yang diterapkan untuk tujuan ini adalah dengan pembelajaran PAKEM. Pembelajaran ini merupakan pembelajaran aktif yang menekankan pada keterlibatan siswa secara aktif untuk mengalami sendiri, menemukan, memecahkan masalah sehingga sesuai potensi mereka berkembang secara optimal. PAKEM adalah singkatan dari Pembelajaran Aktif, Kreatif, Efektif dan Menyenangkan. Pada dasarnya ini merupakan penggunaan istilah yang berbeda dari pembelajaran aktif (Active Learning) ataupun pembelajaran kontekstual (CTL) namun mempunyai makna yang sama.

Tugas wartawan yang pertama yakni, authenticator, yakni konsumen memerlukan wartawan yang bisa memeriksa keabsahan suatu informasi. Kedua adalah sense maker yakni menerangkan apakah informasi itu masuk akal atau tidak. Tugas ketiga adalah investigator, yakni wartawan harus terus mengawasi kekuasaan dan membongkar kejahatan. Keempat adalah witness bearer, yakni kejadian-kejadian tertentu harus diteliti dan dipantau kembali dan dapat bekerja sama 
dengan reporter warga. Adapun tugas kelima adalah empowerer yakni saling melakukan pemberdayaan antara wartawan dan warga untuk menghasilkan dialog yang terusmenerus pada keduanya. Keenam adalah smart aggregator, yakni wartawan cerdas harus berbagi sumber berita yang bisa diandalkan, laporan-laporan yang mencerahkan, bukan hanya karya wartawan itu sendiri. Ketujuh adalah forum organizer, yakni organisasi berita, baik lama dan baru, dapat berfungsi sebagai alun-alun di mana warga bisa memantau suara dari semua pihak, tak hanya kelompok mereka sendiri. Adapun tugas kedelapan, role model, yakni tak hanya bagaimana karya dan bagaimana cara wartawan menghasilkan karya tersebut, namun juga tingkah laku wartawan masuk dalam ranah publik untuk dijadikan contoh (Kovach, Bill, 2014; Kovach \& Rosenstiel, 2010). Tugas dari seorang wartawan adalah reporting. Reporting adalah bentuk pelaporan yang memerlukan kemampuan untuk melaporkan dan menulis tentang berbagai topik. Wartawan melakukan pelaporan dalam berbagai outlet berita, seperti surat kabar, stasiun televisi berita, dan stasiun radio berita, dimana tugasnya mengumpulkan berita.

\section{METODE}

Metode penelitian yang penulis gunakan adalah metode penelitian eksperimen kuasi dengan pendekatan kuantitatif. Pendekatan kuantitatif digunakan untuk memperoleh gambaran tetang kemampuan siswa menulis laporan hasil wawancara melalui teknik 'Menjadi Wartawan Junior'. Selain itu, penelitian ini juga menggunakan pendekatan kualitatif untuk mendeskripsikan data profil kemampuan siswa dalam menulis laporan hasil wawancara melalui teknik 'Menjadi Wartawan Junior' sebelum pendekatan pembelajaran menulis melalui teknik 'Menjadi Wartawan Junior' diterapkan. Untuk mendapatkan data penelitian, peneliti menggunakan instrument tes, lembar observasi, dan angket (Creswell, 2003; sugiyono, 2014)

Eksperimen kuasi yang penulis maksudkan adalah jenis eksperimen (menurut Frankel dan Wallen) yaitu penelitian yang melibatkan kelas pembanding. Dalam artian penelitian melibatkan kelas uji coba dan kelas kontrol. Hasil yang diinginkan dapat diketahui melalui proses sebelum dan sesudah perlakuan. Kelas uji coba dan kelas control yang penulis gunakan adalah siswa kelas V SDN Padasuka 1 sebagai kelas uji coba dan kelas V SDN Padasuka 2 sebagai kelas kontrol. Desain penelitian ini merupakan bentuk disain kuasi eksperimen (nonequivalent control group design) dengan menggunakan dua kelas yaitu kelas eksperimen dan kelas kontrol. Pertimbangan penggunaan disain ini karena dalam penelitian ini kelompok eksperimen dan kelompok kontrol tidak dipilih secara random, selain daripada itu sulit sekali menemukan kelas yang memiliki karakteristik yang sama persis. Disain ini memiliki kelompok kontrol namun tidak dapat berfungsi sepenuhnya untuk mengontrol variabel-variabel luar yang mempengaruhi pelaksanaan eksperimen (Sugiyono, 2014).

Untuk memperoleh data pada kelas tersebut diberikan pretes dan Postest. Perbedaan antara kedua kelas tersebut adalah perlakuan dalam proses pembelajaran, dimana kelas eksperimen pembelajarannya menggunakan teknik 'Menjadi Wartawan Junior', sedangkan kelas kontrol pembelajarannya menggunakan teknik diskusi, tanyajawab, dan ceramah. Sehubungan dengan desain seperti di atas, Sugiyono (2007,p.116) mengatakan bahwa pada jenis desain eksperimen ini terjadi pengelompokan subjek tidak secara acak, adanya pretes $\left(\mathrm{O}_{1 \text { dan }} \mathrm{O}_{3}\right)$, dan ada Postest $\left(\mathrm{O}_{2}\right.$ dan $\mathrm{O}_{4}$ ). Kelas yang satu memperoleh perlakuan pembelajaran dengan teknik 'Menjadi Wartawan Junior' (X), sedangkan kelas yang satu lagi tidak memperoleh perlakuan.

\section{HASIL DAN PEMBAHASAN}

Hasil dari penelitian ini adalah data yang menunjukkan keefektifan model PAKEM melalui teknik 'Menjadi Wartawan Junior' dalam pembelajaran menulis berita siswa kelas $\mathrm{V}$ tingkat sekolah dasar A sebagai kelas eksperimen dan kelas B sebagai kelas kontrol. Penelitian ini dilaksanakan dari Agustus - 
Oktober 2013. Penelitian ini dilakukan pada dua kelas yang dianggap dapat mewakili keterujian hasil penelitian, yaitu satu kelas sebagai kelas eksperimen sebanyak 36 siswa dan satu kelas sebagai kelas kontrol sebanyak 36 siswa. Adapun untuk penentuan kelas eksperimen dan kelas kontrol, peneliti menentukan langsung masing-masing kelas yang dipilih sebagai kelas eksperimen dan kelas kontrol. Karena keduanya memiliki karakter sama berdasarkan hasil perhitungan normalitas, homogenitas, dan realibilitas. Kelas eksperimen merupakan kelas yang mendapatkan perlakuan menggunakan model PAKEM melalui teknik 'Menjadi Wartawan Junior' dalam pembelajaran menulis berita, sedangkan kelas kontrol tidak mendapatkan perlakuan yaitu menggunakan model pembelajaran konvensional. Namun, agar tidak terlalu timpang dalam pelaksanaan penilaian maka pada kelas kontrol pembelajaran menggunakan metode ceramah dan diskusi. Berikut ini dipampang kedua sekolah tempat penelitian.

Uji normalitas dimaksudkan untuk mengetahui apakah selisih nilai pre-test dan post-test dari kelas eksperimen dan kelas kontrol, serta gain post-test dari kelas eksperimen dengan kelas kontrol berdistribusi normal atau tidak. Pengujian kenormalan data dilakukan menggunakan uji Liliefors yang diolah mengunakan SPSS. Kriteria pengujian adalah jika signifikansi lebih besar dari 0.05 maka data dikatakan berdistribusi normal. Hasil pengujian kenormalan dapat dilihat secara detail rangkuman data seperti tabel di bawah ini.

Tabel 1. Uji Normalitas Data

\begin{tabular}{llllll}
\hline \multirow{2}{*}{ No } & Aspek & & Signifikansi & Keterangan \\
\cline { 4 - 5 } & pretes & Postest & Normal \\
\hline 1 & $\begin{array}{l}\text { pretes } \\
\text { eksperimen }\end{array}$ & -Postest & 0.071 & 0.168 & Normal \\
$\begin{array}{l}\text { pretes } \\
\text { kontrol }\end{array}$ & -Postest & 0.051 & 0.230 &
\end{tabular}

\begin{tabular}{llll} 
gain eksperimen & $\begin{array}{l}\text { Signifikansi } \\
\text { eksperimen } \\
\text { kontrol }\end{array}$ & kontrol & \\
& 0.068 & 0.076 & Normal \\
\hline
\end{tabular}

Berdasarkan tabel di atas terlihat bahwa data hasil penelitian berdistribusi normal, karena tingkat signifikansi lebih besar dari 0,05 sehinggga pengujian hipotesis dilakukan dengan menggunakan pairedsamples t-tes. Setelah dilakukan pengujian normalitas terhadap data yang diperoleh, ternyata data tersebut berdistribusi normal. Oleh karena itu, untuk menguji hipotesis digunakan Independent-Samples t-tes dengan menggunakan program SPSS 19,0.

\section{1) Pengujian Hipotesis Kelas Eksperimen} dengan Kelas Kontrol

Hipotesis $\mathrm{Nol}(\mathrm{H} 0: \mu 1=\mu 2)$, Hipotesis pemahaman konsep lingkungan siswa dalam penelitian ini adalah sebagai berikut.Tidak terdapat perbedaan pemahaman konsep menulis laporan wawancara dalam pembelajaran bahasa Indonesia antara yang menggunakan Model Menulis Laporan Wartawan Junior dengan yang menerapkan metode konvensional.

Hipotesis Kerja (H1: $\mu 1 \neq \mu 2)$, Terdapat pemahaman konsep menulis laporan wawancara dalam pembelajaran Bahasa Indonesia antara yang menggunakan Model Menulis Laporan Wartawan Junior dengan yang menerapkan metode konvensional. Pengujian kenormalan data dilakukan menggunakan uji Liliefors yang diolah menggunakan program SPSS 19,0. Kriteria pengujian adalah jika signifikansi $>$ 0.05 maka data dikatakan berdistribusi normal. Berikut ini hasil pengujian kenormalan untuk pemahaman konsep menulis laporan wawancara. 
Tabel 2. Uji Normalitas Data Pemahaman Konsep Menulis Laporan

\begin{tabular}{llll}
\hline No & Variabel & Signifikansi & Distribusi \\
\hline 1 & Eksperimen & 0.068 & Normal \\
2 & Kontrol & 0. & Normal \\
& & 076 & \\
\hline
\end{tabular}

Berikutnya dilakukan perhitungan untuk uji homogenitas dan Independent-Samples t-tes dengan menggunakan program SPSS 19,0.

Tabel 3. Independent T-test

\begin{tabular}{|c|c|c|c|c|c|c|c|c|c|}
\hline & \multirow{3}{*}{$\begin{array}{l}\text { Levene's } \\
\text { Test for } \\
\text { Equality of } \\
\text { Variances } \\
\text { F }\end{array}$} & \multicolumn{8}{|c|}{ t-test for Equality of Means } \\
\hline & & \multirow[t]{2}{*}{ Sig. } & \multirow[t]{2}{*}{$\mathrm{t}$} & \multirow[t]{2}{*}{ Df } & \multirow[t]{2}{*}{$\begin{array}{l}\text { Sig. (2- } \\
\text { tailed) }\end{array}$} & \multirow[t]{2}{*}{$\begin{array}{l}\text { Mean } \\
\text { Differ } \\
\text { ence }\end{array}$} & \multirow[t]{2}{*}{$\begin{array}{l}\text { Std. } \\
\text { Error } \\
\text { Differ } \\
\text { ence }\end{array}$} & \multicolumn{2}{|c|}{$\begin{array}{l}95 \% \text { Confidence } \\
\text { Interval of the } \\
\text { Difference }\end{array}$} \\
\hline & & & & & & & & Lower & Upper \\
\hline Ngain & $\begin{array}{l}\text { Equal } \\
\text { variances } \\
\text { assumed }\end{array}$ & 1,615 & ,208 & 7,452 & 70 & ,000 & 9,250 & 1,241 & 11,726 \\
\hline $\begin{array}{l}\text { Equal } \\
\text { varian } \\
\text { ces } \\
\text { not } \\
\text { assum } \\
\text { ed }\end{array}$ & & & $\begin{array}{l}7,45 \\
2\end{array}$ & 69,181 &, 000 & 9,250 & 1,241 & 11,726 & 6,774 \\
\hline
\end{tabular}

Kelompok kontrol sebesar 7.452, pada df 58 dan tingkat kesalahan $(\alpha)$ sebesar $5 \%$ atau 0.05 (hipotesis dua arah) diperoleh $\mathrm{t}_{\text {tabel }}$ sebesar 2.719. Jika $\mathrm{t}_{\text {hitung }}>\mathrm{t}_{\text {tabel }}(7.452>$ 2.719) atau jika nilai signifikansi sebesar 0.000 $<\alpha \quad$ sebesar 0.05 , maka hipotesis kerja (H1: $\mu 1 \neq \mu 2)$ diterima, maka terdapat perbedaan Test pemahaman konsep menulis laporan wawancara yang signifikan dalam pembelajaran bahasa Indonesia antara yang menggunakan 'Model Menulis Laporan Wartawan Junior' dengan yang menerapkan metode diskusi.

2) Peningkatan Kemampuan Menulis Laporan Hasil Wawancara

Untuk melihat peningkatan kemampuan menulis laporan yang telah dicapai oleh siswa dan kualifikasinya. Skor Gain kemampuan menulis laporan adalah skor yang diperoleh dari selisih skor Postest dengan skor pretes baik pada kelas eksperimen maupun kelas kontrol. Adapun hasil perhitungan gain menggunakan worksheet Excel adalah sebagai berikut. Nilai kemampuan menulis kelas eksperimen kemampuan menulis laporan pada kelas eksperimen diperoleh rata-rata skor pretes 57,47 dan rata-rata skor Postest 78,50. Berdasarkan data tersebut maka diperoleh rata-rata nilai peningkatan (gain) sebesar 21,03. Sehingga dapat disimpulkan, bahwa kemampuan menulis laporan siswa meningkat pada kelas eksperimen yang menggunakan model PAKEM dengan teknik 'Menjadi Wartawan Junior'. Untuk lebih jelasnya disajikan pada grafik di bawah ini. 
Grafik 1. Peningkatan hasil pembelajaran kelas eksperimen

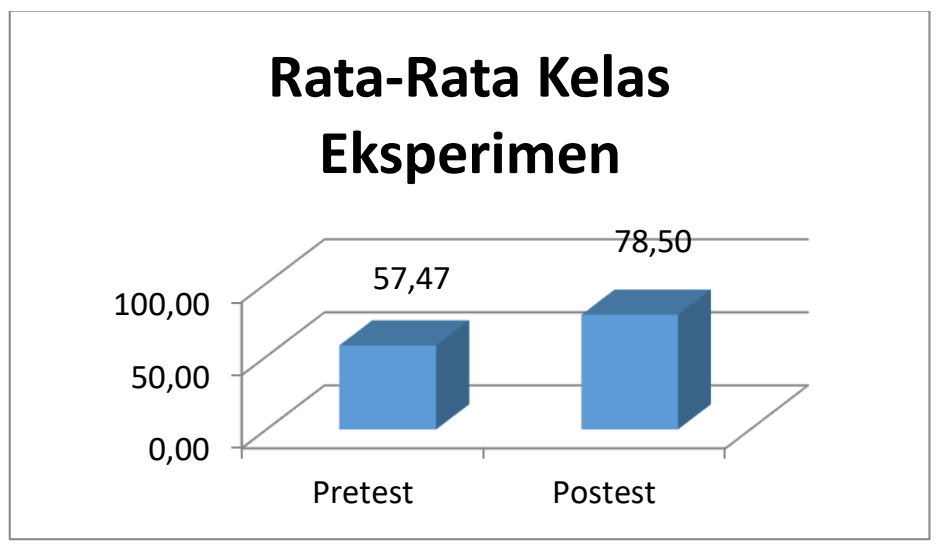

Hasil Penilaian Skor Total Kelas Kontrol menunjukkan rata-rata skor pretes 57,00 dan rata-rata skor Postest 68,78 maka diperoleh rata-rata gain sebesar 11,78. Sehingga dapat disimpulkan, bahwa kemampuan menulis laporan pada kelas kontrol yang menggunakan teknik diskusi mengalami peningkatan. Agar lebih jelas, peningkatan tersebut dapat dilihat pada grafik berikut.

Grafik 2. Peningkatan Hasil Pembelajaran pada Kelas Kontrol

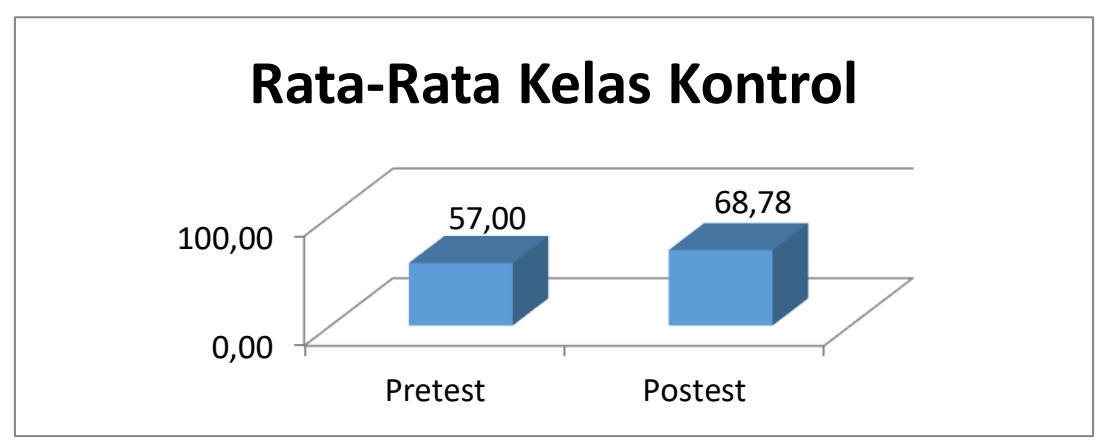

Berdasarkan grafik batang di atas dapat terlihat perbedaan pretes dengan Postest. Terdapat peningkatan kemampuan siswa menulis laporan pada kedua kelas tersebut, namun demikian kelas eksperimen tampak lebih unggul. Untuk lebih jelasnya perbedaan tersebut disajikan pada grafik berikut.

Grafik 3. Peningkatan Postest pada Kelas Kontrol dan Kelas Eksperimen

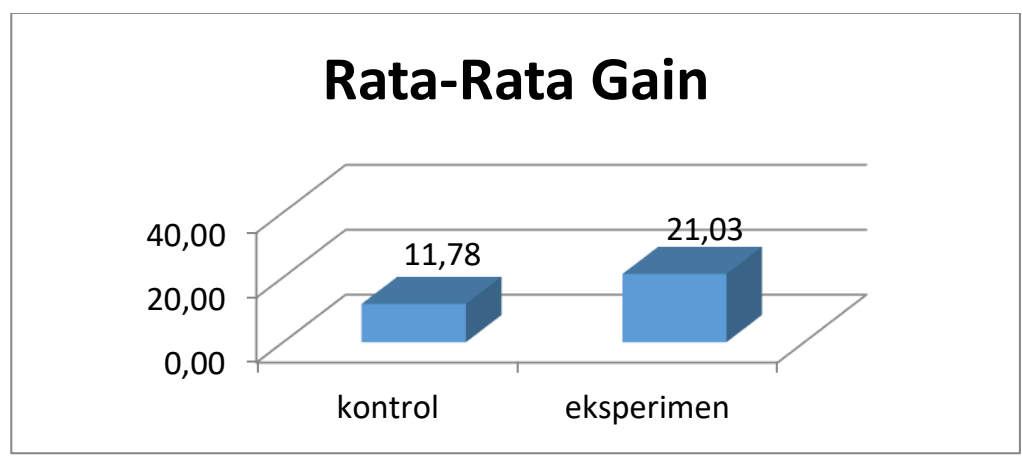


Pada grafik di atas tampaak perbedaan gain hasil Postest masing-masing kelas. Kelas kontrol mendapatkan perbedaan gain pretes Postest sebelas 11,78 dan kelas eksperimen 21,03. Dengan demikian, kelas eksperimen lebih unggul daripada kelas kontrol.

Grafik 4. Perbedaan Peningkatan Postestt pada Kelas Kontrol dan Kelas Eksperimen

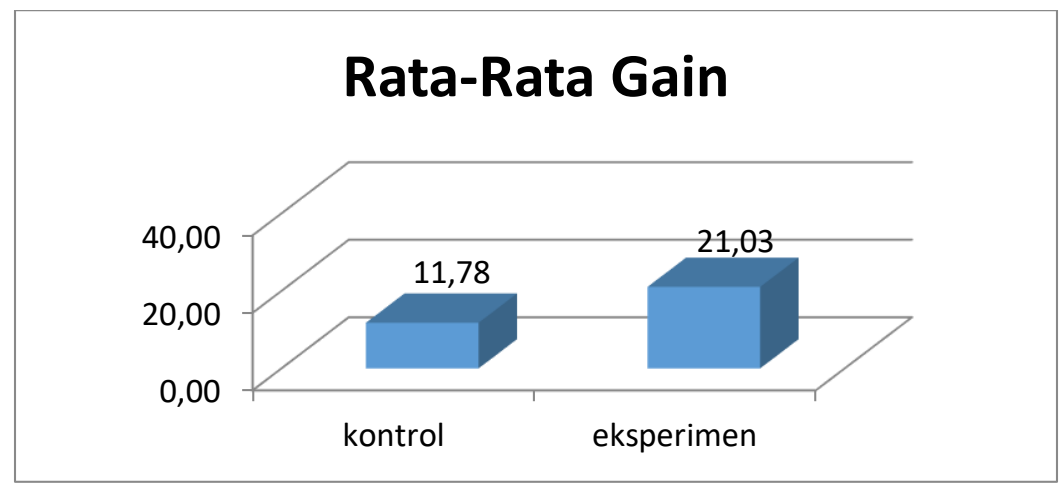

Dari grafik di atas, terlihat jelas bahwa terbukti model PAKEM melalui teknik 'MenjadiWartawan Junior' mampu meningkatkan kemampuan menulis laporan. Hal ini bukan tanpa alasan, sebuah suasana pembelajaran yang aktif, kreatif dan menyenangkan, pembelajaran berbasis aktivitas siswa, dan pembelajaran yang menitikberatkan pada proses dalam menulis, telah merangsang siswa untuk menghasilkan tulisan yang baik. Menurut Kemdikbud (2010) model PAKEM melalui teknik 'MenjadiWartawan Junior' bermakna jika pelajar belajar interaksi dengan tulisannya. Dengan demikian, siswa bukan hanya sudah mampu berinteraksi dengan lingkungannya, namun berinteraksi dengan pengalamannya sendiri.

Pada pelaksanaan pembelajaran menulis laporan melalui penerapan model PAKEM melalui teknik 'MenjadiWartawan Junior', siswa mempunyai kebebasan untuk menentukan tema atau topik, dengan demikian seluruh potensi siswa dapat terekplorasi dengan baik. Dalam hal ini, guru berperan untuk membimbing siswa dalam rangka menghasilkan tulisan yang baik. Kondisi ini sesuai dengan pernyataan, Sanjaya (2010) yang menjelaskan bahwa mengajar dalam konteks standar proses pendidikan tidak hanya menyampaikan materi pelajaran, akan tetapi juga dimaknai sebagai proses mengatur lingkungan supaya siswa belajar.

Sebuah pembelajaran menulis menghantarkan siswa untuk menikmati tahap demi tahap pembelajaran sehinggga mampu memproduksi sebuah karya dalam bentuk laporan. karangan narasi ekspositorik. Menulis akan menjadikan siswa berlatih menyusun karangan secara sistematis dan menjadikan ia mampu berpikirserta menata gagasan. Hal ini tentu dengan bimbingan yang diberikan oleh guru dalam pembelajaran menulis laporan pada kelas eksperimen. Dengan demikian kondisi pembelajaran melalui model PAKEM melalui teknik 'MenjadiWartawan Junior' telah seiring sejalan dengan prinsip fungsional pembelajaran bahasa(Farkas, 2005; Mountford, 2010). Linguistik fungsional dalam pembelajaran bahasa berbasis teks. Dalam halini, pembelajaran bahasa diawali dengan pemodelan teks, membangun konteks, bekerja sama dalam kelompok menyusun teks, dan menyusun teks secara mandiri (Raban, 1987; Sazzad, 2019).

Kondisi di atas tentunya berbeda dengan pembelajaran pada kelas kontrol yang masih terpaku pada pendekatan tradisional. Pembelajaran pada kelas kontrol lebih menekankan pada bagaimana siswa mampu menulis laporan tanpa disertai dengan suasana pembelajaran yang menunjang 
ketercapaian hasil belajar. Hal ini ditandai dengan proses pembelajaran yang masih berfokus pada guru. Guru merupakan satusatunya ahli untuk merevisi hasil tulisan siswa, selain itu langkah-langkah pembelajaran tidak menunjukkan bahwa menulis merupakan proses. Siswa hanya diajak berdiskusi saja. Keberhasilan tersebut merupakan gambaran bahwa guru berhasil menciptakan pengembangan pendekatan pembelajaran menggunakan model PAKEM melalui teknik 'MenjadiWartawan Junior' untuk menciptakan pembelajaran berdasarkan pengalaman mewawancari narasumber masing-masing individu siswa untuk kemudian dibahas dan diputuskan secara demokratis. Guru memainkan peran penting untuk menuntun diskusi-diskusi kelompok, menciptakan keseimbangan antara siswa, serta membiarkan siswa membuat keputusan-keputusan mereka sendiri demi aktualisasi nilai-nilai karakter dalam pembelajaran. Melalui tahapan-tahapan menjadi wartawan, siswa saling menolong belajar merefleksikan hasil wawancara dan menemukan informasi kemudian ditulis dalam bentuk laporan.

Sekaitan dengan hasil wawancara, laporan yang ditulis tentang latar belakang kesuksesan pedagang paling dominan dalam tulisan siswa, peneliti melihat bahwa aspek kerja sama, semangat, dan teliti merupakan yang paling berhasil diangkat oleh siswa. Dalam hal ini, melalui bimbingan guru dan model yang sesuai dengan materi pembelajaran terbukti bahwa siswa mampu menulis laporan dengan baik Berdasarkan kegiatan pembelajaran tersebut, berikut ini dipaparkan pembahasan terhadap karakteristik model pembelajaran (Black, 2004). Langkah-langkah kegiatan yang dilakukan dalam model ini adalah : (1) Mengamati, dalam hal ini siswa menyaksikan film, menganalisis unsur-unsur intrinsik film, mengamati persamaan dan perbedaan ciri suatu benda, mengidentifikasi contoh teks, menganalisis karya teman, dan memublikasikannya. (2) Menanya, dalam hal ini siswa bertanya jawab perihal materi, tayangan video menjadi drama, berdiskusi (bertanya, menjawab, mengambil kesimpulan, mendengar penjelasan, mengajukan gagasan), dan mengarang, merencanakan dan menulis laporan. Kemudian siswa mengidentifikasi contoh teks. (3) Mencoba, dalam hal ini siswa berdiskusi, berwawancara, menyusun laporan, dan bermain peran menjadi reporter berita. (4) Menalar, siswa menuliskan laporan hasil wawancara dan diskusi. Selain itu (5) memublikasikan, dalam hal ini siswa melakukan diskusi dengan teman ataupun dengan guru dan mengomentari karya teman ketika mengomunikasikan laporan. Ketika menerapkan model pembelajaran ini, guru harus berusaha melihat dunia yang ada dalam pikiran siswa, menciptakan atmosfer komunikasi yang sarat dengan empati sehingga arah dan pendirian pribadi siswa dapat dibimbing dan dikembangkannya. Selama interaksi tersebut berlangsung, guru merefleksikan pemikiran dan perasaan siswa. Dengan demikian, menggunakan komentar yang reaktif, guru membangkitkan kesadaran siswa terhadap persepsi dan perasaan mereka, lalu membantu mereka mengklarifikasi gagasan-gagasannya.

Kemampuan menulis meningkat karena keaktifan peserta didik secara tidak langsung mengasah kemampuan dan keterampilan menguasai berbagai unsur pembelajaran. Terakhir, pengaruh keaktifan terhadap kemampuan menulis laporan meningkat. Hal ini disebabkan dalam praktik pembelajaran siswa mendapatkan contoh berinteraksi dalam kelas, mengidentifikasi video, mendidik melalui pelatihan, dan lainlain. Keaktifan siswa dalam pembelajaran secara tidak langsung memandu siswa untuk menjadikan pembelajaran menarik dan menyenangkan. Ini berdampak pada menciptakan efek kepercayaan diri yang lebih dari siswa untuk selanjutnya berkreasi menyampaikan gagasan lainnya.

Hasil penelitian ini memiliki dampak positif. Pengaruh tersebut senarai pula dengan pendapat Depdiknas (2008) bahwa kelebihan model PAKEM dengan teknik 'Menjadi Wartawan Junior' ini di antaranya pembelajaran menjadi efektif, efisiensi, dan memiliki daya tarik pembelajaran terhindar dari kebosanan karena siswa mengikuti 
berbagai variasi kegiatan. Kegiatan pembelajaran PAKEM dengan teknik 'Menjadi Wartawan Junior'dalam penelitian ini antara lain berupa (1) mendiskusikan dan mengapresiasi tayangan video, (2) menciptakan permainan, (3) berdiskusi (bertanya, menjawab, mengambil kesimpulan, mendengar penjelasan, mengajukan gagasan), (4) mewawancarai penjual di sekitarlingkungan sekolah, (5) merencanakan dan melakukan kerja sama dalamkelompok, (6) membuat laporan, (7) wawancara, (8) mengidentifikasi video, (9) menganalisis unsur-unsur intrinsik video, (10) mengamati persamaan dan perbedaan ciri suatu benda, (11) mengidentifikasi contoh pertanyaan dan teks, (12) menganalisis karya teman, (13) berpendapat, (14) reporter TV, (15) merefleksi pembelajaran, dan (16) mengomentari karya teman.

\section{SIMPULAN}

Berdasarkan hasil penelitian yang telah dikemukakan pada bab sebelumnya, diperoleh simpulan, yaitu sebagai berikut. Rancangan pembelajaran menulis dengan model PAKEM melalui teknik 'Menjadi Wartawan Junior' terdiri atas kegiatan orientasi tugas wartawan, menyusun pertanyaan wawancara, melakukan wawancara, menulis laporan hasil wawancara. Karakteristik pembelajaran menulis dengan model PAKEM melalui teknik 'Menjadi Wartawan Junior' yaitu pembelajaran menyenangkan, pengalaman bermain peran menjadi wartawan, menyusun pertanyaan, mewawancarai dengan bekerja sama dan penuh kesantunan, mengumpulkan data, berdiskusi, mencoba menulis laporan, dan mengomunikasikannya. Dalam hal ini, multimedia berupa film sangat berperan sehingga mampu mengaktifkan siswa dan menjadikan pembelajaran menyenangkan. Oleh karena itu, film dapat dijadikan sebagai bahan ajar dalam pembelajaran PAKEM dengan teknik 'Menjadi Wartawan Junior'.

Dalam model pembelajaran PAKEM dengan teknik 'Menjadi Wartawan Junior', siswa dilatih untuk meningkatkan kemampuan berbicara dalam peranannya sebagai wartawan. Namun, sebelum menampilkan kemampuannya, siswa perlu memahami tema yang akan ditulisnya. Profil kemampuan menulis sebelum pembelajaran dengan model PAKEM melalui teknik 'Menjadi Wartawan Junior' yaitu rata-rata 57,47 dan sesudahnya rata-rata 78,50. Teknik 'Menjadi Wartawan Junior' efektif untuk meningkatkan kemampuan siswa menulis laporan dengan tingkat signifikansi 7,452 yaitu dengan $t_{\text {hitung }}>\mathrm{t}_{\text {tabel }}(7.452>2.719)$ atau jika nilai signifikansi sebesar $0.000<\alpha$ sebesar 0.05, maka hipotesis kerja (H1: $\mu 1 \neq$ $\mu 2)$ diterima. Hal ini dibuktikan pula pada kemampuan kelas eksperimen dengan kenaikan rata-rata skor pretes 57,47 menjadi 78,50 pada rata-rata skor Postest. Sementara, rata-rata akhir nilai kelas kontrol sebesar 57,00 pada pretes dan meningkat 68,78 pada rata-rata skor Postest. Terdapat perbedaan gain sebesar 21,03 pada kelompok eksperimen dan11,78 pada kelompok kontrol.

Pembelajaran menulis dengan teknik 'Menjadi Wartawan Junior' dapat terlaksana sesuai dengan sintaksnya selama enam kali pertemuan. Setiap langkah pembelajaran yang dilaksanakan sudah mencerminkan langkah-langkah pembelajaran teknik 'Menjadi Wartawan Junior'. Guru yang mengajar pelajaran bahasa Indonesia juga menyatakan bahwa pembelajaran bahasa Indonesia dengan teknik 'Menjadi Wartawan Junior' sangat relevan untuk diterapkan dalam meningkatkan kemampuan menulis siswa pada mata pelajaran bahasa Indonesia. Namun terdapat kendala yaitu kemampuan menulis yang belum terlatih, sarana yang serba terbatas (tidak ada komputer, kurang fasilitas perpustakaan), dan kebiasaan lingkungan belajar yang belum menggunakan PAKEM karena jumlah siswa yang banyak.

\section{DAFTAR RUJUKAN}

Abdurrahman, M. (2009). Pendidikan Bagi Anak Kesulitan Belajar. Jakarta: Rineka cipta.

Black, J. M. (2004). Assessing learning preferences. Plastic Surgical Nursing, 24(2).

Centeno Vazquez, M. A. (2013). Factors related 
to early writing development. ProQuest Dissertations and Theses. Creswell, J. W. (2003). Creswell, J.W. Research design Qualitative quantitative and mixed methods approaches.

Depdiknas. (2006). Permendiknas No 22

Tahun 2006 Tentang Standar Isi. Jakarta : Depdiknas

Epstein-Jannai, M. (2007). Writing to Learn: Constructing the Concept of Genre in a Writing Workshop (pp. 349-365). https://doi.org/10.1007/978-1-40202739-0_24

Eslava-Schmalbach, J., \& Gómez-Duarte, O. G. (2013). Scientific writing, a neglected aspect of professional training. Revista Colombiana de Anestesiologia, 41(2), 79-81.

Farkas, D. K. (2005). The Concept of Consistency in Writing and Editing. Journal of Technical Writing and Communication, 15(4), 353-364. https://doi.org/10.2190/t6em-utt0el6j-59n9

Favis, M. C. (2009). The concept of writing, with continual reference to "Kierkegaard." European Legacy.

KoUn. (2014). Analysis on Factors That Influence the Writing Skill Development of Preschoolers. Journal of Speech-Language \& Hearing Disorders, 16(2), 109-129.

Kovach, B., \& Rosenstiel, T. (2014). Chapter 4: Journalism of Verification. In The Elements of Journalism: What Newspeople Should Know and the Public Should Expect. https://doi.org/10.1016/j.jad.2015.02. 010

. (2010). Blur: How to know what's true in the age of information overload. Publishers Weekly.

k\%5Cnhttp://books.google.com/book $\mathrm{s} ? \mathrm{hl}=\mathrm{en} \& \mathrm{amp}$

Kress, G. (1980). The development of the concept of "sentence" in children's writing. Australian Review of Applied Linguistics, 3(2), 63-75. https://doi.org/10.1075/aral.3.2.06kre

Leontis, A. (2019). Writing. In Eva Palmer Sikelianos (pp. 174-223).

Lerner, N. (2007a). Laboratory lessons for writing and science. Written
Communication, 24(3), 191-222.

Lerner, N. (2007b). Laboratory Lessons for Writing and Science 10.1177/0741088307302765. Written Communication. Retrieved from

Lerner, N. (2017). WRITING CENTER ASSESSMENT: In Center Will Hold (pp. 58-73).

Mountford, J. (2010). Writing-system as a concept in linguistics. Information Design Journal, 1(4), 223-231.

Nimehchisalem, V. (2014). Materials for Assessing the Writing Skill. Advances in Language and Literary Studies, 1(2), 233255.

Raban, B. (1987). The concept of narrative in children's writing. Language and Education, 1(2), 97-107.

Rohrman, N. L. (2006). Educators Writing About Writing. Contemporary Psychology: A Journal of Reviews, 32(3), 265-265.

Sazzad, R. (2019). The Place of Writing in Exile. In Edward Said's Concept of Exile.

ugiyonoS. (2014). Metode penelitian. Metode Penelitian, 35-49.

Tarigan, H. G. (2008). Peningkatan Keterampilan Menulis Karangan Deskripsi Menggunakan Media Diorama Siswa Kelas IV. Pendidikan Guru Sekolah Dasar, 1. 